\title{
WILL ROMANIA'S STRATEGY OF DEVELOPMENT AFFECT THE INTEGRATION OF THE SUSTAINABLE DEVELOPMENT IN THE ACCOUNTING OF ROMANIAN ENTITIES?
}

\author{
Maria-Mădălina Bogeanu-Popa \\ Doctoral School of Economic Sciences, Faculty of Economics and Business Administration, \\ University of Craiova, Craiova, Romania \\ madalinabogeanu@yahoo.com
}

\begin{abstract}
This paper presents the influence that the sustainable development strategy has over the economic environment and especially over the national accounting model. Generally, the strategies of the sustainable development are carefully monitored and the periodic evaluation of them is a defining element. The processes involved in the evolution of the economic activities support the pylons of sustainable development and it integrates in this process the future request and offer. The elaboration of these strategies in the long run represents a primordial objective of the economic entities. The function of foresight from within the accounting model is used to showcase the strategy and to establish the mission that the economic entity has. By actively involving the accounting model, the internal and external information is contained into one single process. A different reason for which the accounting model is headed towards this direction is the fact that the objectives established in the long run contain at least one of the different environmental, social and economic factors, achieving at least one specific pylon of the sustainable development. Discussing assumed objectives, organizing programs and strategies of education and improvement in the field of sustainable development are key elements. These can be analyzed carefully within the entity and can guide the economic activity towards planning the strategy starting from its own accounting model. Respecting everything that has been mentioned, the integration of the sustainable development's aspects needs to complete the process of sustainable development specific to the economic entity's objectives and the accounting model.
\end{abstract}

Keywords: Sustainable development, strategy, accounting model, objectives.

JEL classification: M40, M41, M49.

\section{Introduction}

The complete process of the sustainable development is composed of small structures headed towards promoting strong points and improving weak ones. The sustainable development represents all that has been debated after 1980 and it is characterized by the economic, social and environmental pylons (Platon, 1997). This being said, the sustainable development is present in various domains, especially the economic one (Smith, 1975). Through this paper we plan to highlight the way of interaction of the sustainable development strategy with the process of integrating the demands of sustainable development within the national accounting model. It has been proven that the structure and the way the current strategy acts target large horizons of time, referring in this case to 2020-2030. The sustainable development strategy has as points of interest domains like the cultural patrimony, the human capital by investing in qualified workforce and improving the quality of life, the equality between chances, the integration of vulnerable groups, fighting poverty and stopping migration. Due to the implication of the strategy having a ray of action 
within so many domains, we realize the fact that this intervenes in the process of sustainable development but we do not consider it affects the integration of the accounting model during this process. Starting from the common purpose and the strategy of the sustainable development we concentrate on the domains of action. The development strategy print is noticed especially in the economic domain by highlighting actions and changes. Through this paper we plan to find and answer the impact that Romania's development strategy has when it comes to integrating the demands of sustainable development in the Romanian accounting model.

\section{Brief Literature Review}

The period of time proposed in the strategies of sustainable development gets the sustainability of the consumptions and the raw materials, the synchronizing of the economy with the environment and the social, as well as getting rid of the issues of the labor market going by creating an equitable report between the labor market and productivity (Gherasim, 2002). Setting up the managerial structure, the political stabilization and attracting more financing sources lead to the accomplishment of balance and its maintaining for a longer term (Popescu, 1999). The programs of regional development that Romania has used are a good start that deserves a continuity in use (Cramer, 2004). The comparison between presenting the strategy of sustainable development in European context and the strategy of national sustainable development focuses on domains like the cultural patrimony, the human capital by investing in qualified workforce and improving the quality of life, the equality between chances, the integration of the vulnerable groups, fighting poverty and stopping migration (Cămășoiu, 1994).

\subsection{The importance of the strategic management regarding sustainable development in the macroeconomic context}

In a macroeconomic context, the GDP (Gross domestic product) is the carefully monitored indicator even when its being watched through the perspective of sustainable development. The current tendency is the continuous promotion of the GDP growth, a growth that represents a high level of efficiency in investments, a grown productivity of the production factors and a careful monitoring of the consumption of the natural resources through the accounting management.

The annual rate of inflation represents a part of the objective of the sustainable economic growth in the context of the management of sustainability. Maintaining the inflation rate at a level between $1 \%$ and $5 \%$ is a challenge hard to accomplish. It is a known fact that inflation comes down to the economic, social and environmental pylons of sustainable development by damaging them, increasing the risk and the degree of uncertainty. Stopping this effect and the control of the inflation can be done by lowering the costs, as well as the unitary consumption of environmental, social and personnel resources. The growth of the competitiveness and a faster production than a wage growth contributes to these. Referring to the pylons of the sustainable development, mostly the economic pylon, it contributes to the growth of employment, of the productivity degree having the effect of reducing the unemployment (Dachin et al, 2003).

Reviewing The World Summit on Sustainable Development that took place in Johannesburg in 2002, the strategic activities specific to the premises of sustainable development are established considering the Summit's recommendations (Dima and Man, 2003). So, the concern of the states that are under the process of development towards thought, elaboration and monitoring their own strategies of sustainable development is being reminded to us. At the moment, the indications issued by the Summit in 2002 are still available, as not defining the strategies of the economically sustainable development to 
establish actions in the long term is a thing that only a handful of states can abuse. Promoting sustainable development in Romania by supporting the growth of a sustainable economy is the effect attained by making the process of accounting financial management more efficient (Man, Nedelcu and Oprea, 2018). By worsening the environmental, social and personnel problems it is easier to find a solution to the technology adaptation and the usage of processes of low risk in the impact of nature. New approaches to the complexity of the sustainable development process and the disparity between the economic-social events and the consequence of their usage led to the phenomenon of sustainable development through the prism of the accounting management. The answer to current challenges of the sustainable development implies a clear establishment of the economic entity's responsibility concerning the environment, the social and the personnel (Caraiani et al, 2015). An improvement to the business model, a review of the risks that the economic entity faces, leads to the consolidation of the activity developed by the entity in the long term. These facts are not a particular situation when it comes to Romania, they are aspects that are universally available when it comes to the countries under development (Man and Ciurea, 2016). Romania has more strategies implemented or under implementation that are known at a national or local level. This implication has its roots in the managerial need and with time, it has reflected over the management strategy that has become a component part of the sustainable development as of now (Man and Vasile, 2012).

\section{Programming and planning the sustainable development at a macroeconomic level in Romania}

According to the studies, (National Agency for Enviromental Protection, 2018), the strategic plan of Romania for 2020-2030 seems to be the perfect formula for achieving European standards regarding the social, environment and economy. In the context of globalization, Romania needs to resist competition, the circulation of goods and the market, not only for a short while but in the long term as well. As part of the European Union, Romania is aligned at its specific and has in implementation "The National Strategy for Sustainable Development of Romania Horizons 2013-2020-2030" (Ministry of Environment, 2008). Focusing on the proposed changes in Romania for 2020-2030 in figure no. 1 are presented areas to be established and on what is being done to accomplish them and finalize the actions proposed in the strategy, the attention is directed towards the conservation of natural resources, the domain of transport, of production and consumption and the domain of climatic changes.

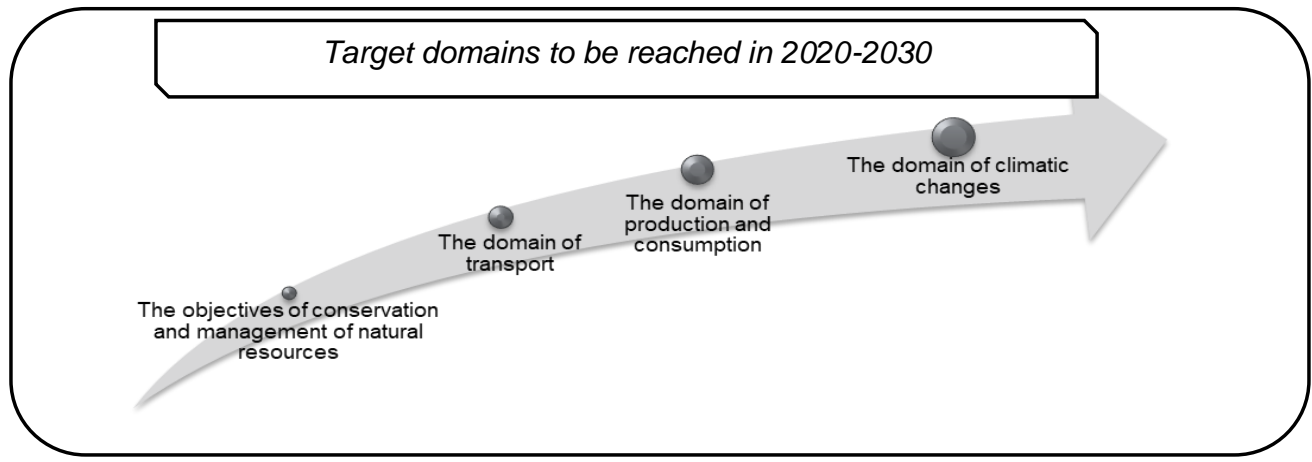

Figure 1: Established domains in the National Strategy of Romania

Source: The projection of the author based on the National Strategy of Durable Development of Romania,

[Online] Available

at:

http://www.mmediu.ro/beta/wp-content/uploads/2012/06/2012-0612dezvoltaredurabilas nddfinalromana2008.pdf. 
The natural resources are managed and appreciated through the objectives of sustainability of the European Union. Romania is just as conscious because it has programs implemented that target the water quality, waste management, reducing the negative factors produced due to global warming, the protection of the natural patrimony and biodiversity. It is reminded to us the Natura 2000 program (Natura 2000 Coalition Romanian Federation, 2018), and last but not least the prevention of natural disasters and decreasing the risk of them happening. The future plans of Romania between 2020-2030 foresee the allocation of the required sums to continue already started projects and to be able to rise to Europe's level with the careful redirection of the actions towards sustainable development.

In the domain of sustainable transport, the objective of the European Union is to reduce as much as possible the negative effects regarding the environment as well as supporting and satisfying the needs of the economic society. For 2020, Romania wants to make progress within infrastructure to be recognized by the European Union and for 2030 it wants to fit transportation in the requirements of the sustainable and European developments which would be at a considerably higher level and closer to the European Union's average.

The consumption and production of Europe follow the principle of sustainability. Romania's situation is of disparity between production and consumption. There is no equitable model to allow support, resorting to import. This is visible in the final price which slows down the access of every individual when buying different products and more than that it is about a chaotic consumption, over the necessary needs. For this situation to be fixed, industries that our country can exploit and develop in a sustainable way intervene, fact that boosts economy and the quality of life. For 2020, the Romanian proposal is to promote a sustainable production and consumption by increasing the value. This reported to consumption influences economic activities which promote environmental erosion. The year 2030 brings Romania a performance of the sustainable production and consumption, something that can be achieved by finalizing the process of public awareness.

In the domain of climatic changes, the target of the strategic objective is that of it being done under conditions of efficiency and to be able to achieve the existent level in Europe.

Promoting the strong points and improving the weak ones is advised. The period of time proposed in the strategy can put in motion the sustainability of consumptions and prime materials, synchronizing the economy with the environment and the social and removing the issue of the labor market creating an equitable report between the labor market and productivity. It is necessary to stabilize the managerial and political structure and to attract as many financing sources as possible and in the end to achieve balance and to maintain it. The complete development is composed of small structures headed towards development. The regional development programs that Romania has reached out to are a good start that deserves a continuity in application, for a shared development at a regional level concentrates the economy and diminishes stagnation, it attenuates imbalances and it facilitates access in disadvantaged areas. Spatial organization and its structuring depends on the infrastructure which, after it is stabilized, it complies with European standards of sustainable development.

Outlining the objectives and the regional development strategy's structure has high goals which need implication and coordination, but Romania already has an advantage.

Aligning to the European Union's standards is not at all a foreign subject for our country, but the disadvantage is that the standards have evolved in a rather small manner in comparison to the level of other countries. 


\section{The methodology of research}

When it comes to the approached methodology, the paper is based on a qualitative research, made as a result of the analysis of the theoretical approaches about the macroeconomic context of the sustainable development. The choice of qualitative research is due to the fact that the depth of the analyzed concepts can be developed through this manner. The method of comparison is present by comparing the European strategy of sustainable development and the Romanian one.

As informational sources, the paper is based on books, articles published in specialty magazines, websites and excerpts from the National Strategy of Development of Romania. The inductive and deductive mechanisms lead to research towards the wanted direction to establish the exhaustive analysis of every aspect tied to the implications of sustainable development in a macroeconomic context. Considering these, the paper has the role of approaching macroeconomic aspects and every detail involved in the demands of this subject. A brief review of the National Strategy of Development of Romania and specialty literature contributes with the understanding of the sustainable development's aspects at a macroeconomic level. Calling out to the analysis of the content and the review, the presented text can be considered a documentary type paper.

The steps taken to accomplish the article are: planning, collecting data, analyzing data and ultimately drafting the article.

\section{Romania's national strategy for sustainable development. Horizons 2020-2030}

In a broad sense, Romania's national strategy of sustainable development for 2020 is its alignment to the actual environmental standards of the European Union and for 2030, reaching the European Union's level of sustainable development existing at that moment is desired (Ministry of Environment, 2008). For Romania, this process would mean a period of continuous growth economically and socially and the integration of the country to the European Union's standards of sustainable development. Figure 1 meets every necessary elements for the sustainable development's strategy planned for 2020-2030.

Our country took part in these problems, fighting the effects of global warming, bringing in a modern world satisfaction and assurance of the energy necessary. By respecting the premises of sustainable development it was possible to reduce emissions with greenhouse effect, a significant gesture which has been well seen by Europe. Romania's work does not stop here as it has to reach the European Union's level in domains like: energy (producing energy at a national level and trying to get rid of import). In Table 1, Section I. I.Estimates in the domain of climatic changes, the growth proposed to be reached in the future, concentrating on electricity from regenerative sources, the decrease of primary energy consumption and final energy is presented.

Romania's strategic objective in 2020 towards the climatic changes and the energy ones is that of it being realized under conditions of efficiency and to be able to reach the existent level in Europe.

Our country has assumed the obligation to accomplish the assumed environmental conditions. In exchange, for 2030 Romania wants to accomplish every commitment and to place the performance of the climatic and energy indicators at the average level of the European Union.

In the domain of durable transport the objective of the European Union is to reduce as much as possible the negative effects over the environment but at the same time there is the desire to support and satisfy the needs of the economic society. At the moment for Romania, the transports occupy a leading position in the priorities of the sustainable development having direct relations with the economy and the services. When it comes to transports, the road, rail and naval transports are being referred which impose to be corroborated at the 
higher level of European quality. Transports produce negative effects over the environment, polluting by producing harmful substances that cars stream or sound pollution from these. That is why replacing older cars with newer ones is encouraged. Last but not least we are talking about the transport in infrastructure which involves a really good condition of the roads and the improvement of as many roads to facilitate access as possible. In table 1.1 section II.Estimates in the field of transport estimates regarding these aspects are presented being estimated a growth of biofuel consumption and a decrease in half in the number of accidents produced due to the growth of road safety.

Table 1: The proposed objectives for 2020-2030

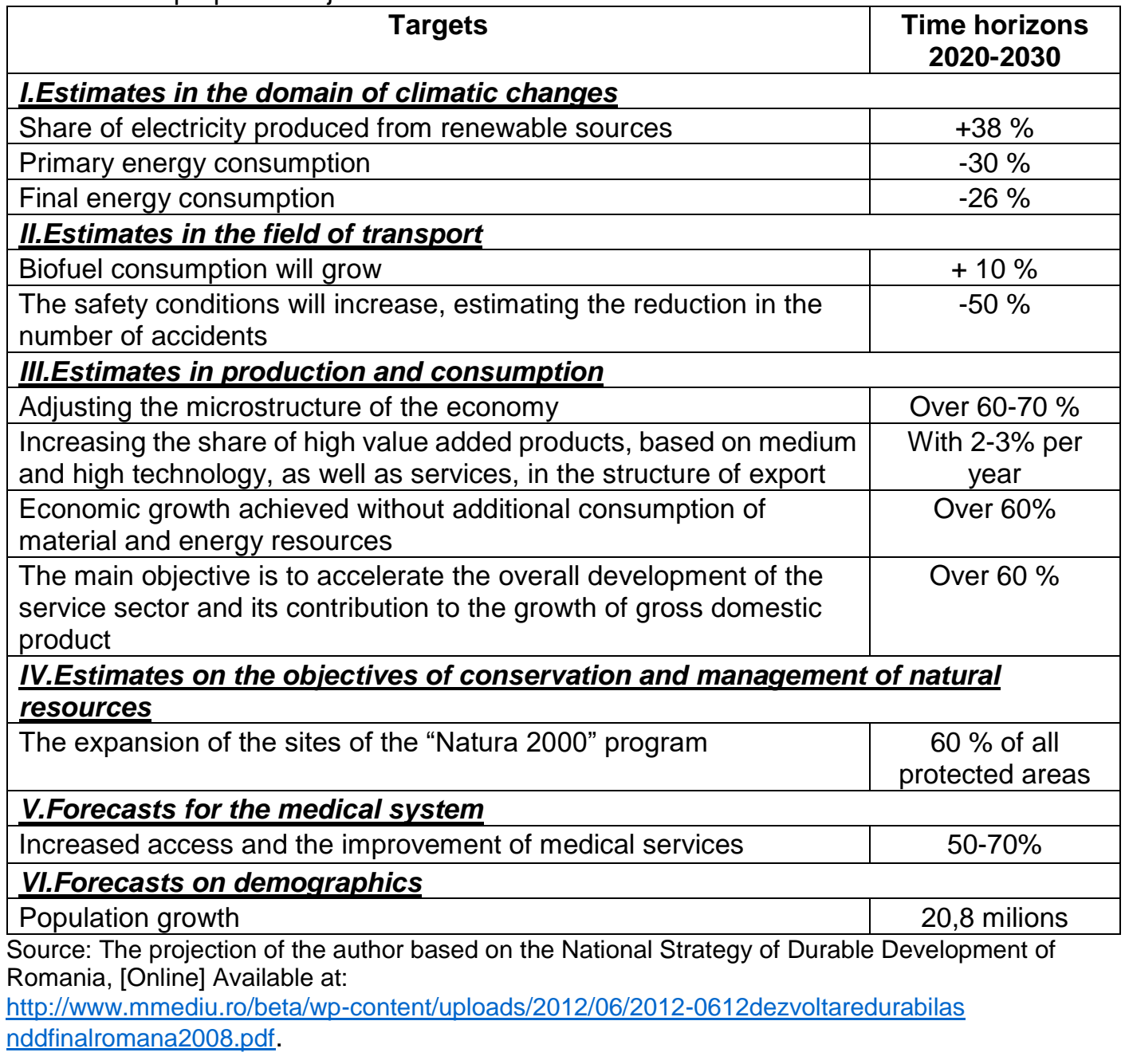

For 2020 Romania proposes to realize progress in infrastructure for it to be recognized by Europe and for 2030 there is desire to classify the transports under the requirements of sustainable and European development which would need to be at a considerably higher level and closer to the average of the European Union.

The consumption and the production of Europe go by the principle of sustainability. The situation of Romania is of disparity between production and consumption. There is no equitable model to allow automatic support and it resorts to import. This shows in the final 
price which slows the access of every individual when they buy different products and more than that we are talking about a chaotic consumption, over the necessary needs. To remedy this situation, industries which our country could exploit and develop in a sustainable way intervene, growing the economy and the quality of life. The estimates towards this direction are presented in Table 1, section III.Estimates in production and consumption. Reaching a percentage of over 60 in economy and especially in the development of the services sector is being estimated.

For 2020 the Romanian proposal is that of promoting a new production and a new sustainable consumption by increasing the value. This thing reported to consumption influences economic activities which promote the destruction of the environment. The year 2030 brings for Romania a performance of production and sustainable consumption by completing the process of public awareness.

The natural resources are managed and appreciated through the sustainability objectives of the European Union. As aware as that is Romania because it has implemented programs which target water quality, waste management, reducing negative factors produced due to global warming, natural patrimony and biodiversity protection. The Natura 2000 program (Natura 2000 Coalition Romanian Federation, 2018) is reminded to us and last but not least the prevention of the natural disasters and diminishing the risk of their happening. Table 1, Section IV.Estimates on the objectives of conservation and management of natural resources the percentage there is the desire to achieve is being presented.

Romania's future plans for 2020-2030 foresee the allocation of the necessary sums to continue the already started projects and to be able to rise to Europe's level with the careful routing of the actions towards sustainable development.

Improving the medical system form a quality point of view is promoted by the European Union though there is no unitary system applicable in European countries. Romania has applied to improve the sanitary system and the directions it has headed are: creating new methods of access to medical services for the disadvantaged individuals to benefit from, a suitable equipping of the medical centers as well as an educated and qualified personnel, a high quality of the services, assuring basic medicine, organizing the management of health in a better way and assuring financing in the long term. The sanitary system could stay in the way of sustainable development by using substances of dangerous nature (Ministry of Environment, 2008). Table 1 Section V.Forecasts for the medical system- is dedicated to the prognosis which estimates to be realized for the medical services improving the access to medical services, the established percentage being between 50 and 70 .

Other than the listed aspects for 2020-2030, there is the desire to reach superior levels of the medical services' qualities and the implementation of new legislative programs at a national level meant to support a sustainable development in relation to the needs of the population. The comparison of the medical services in Romania with the ones of other European countries is being kept in mind as well.

The demography, migration and the social inclusion according to the European Union implies assuring the growth of the life quality level and the wellness of the individuals. The national legislation imposes controlling and combatting the aforementioned by keeping the migratory tendency and the population fluctuation under control. A growth of the population number at 20.8 millions of inhabitants in Romania is ambitiously presented in Table 1, Section VI. Forecasts on demographics. The actions in domains like the equality between chances, including individuals in the labor market, integrating vulnerable groups and last but not least developing the economy under social aspect want to be undertaken in the national strategy.

These actions will be realized by creating a favorable legislative framework, adapting to new, promoting and developing, actions which have a 10 year span between 2020-2030 to be implemented. To establish an order of the Romanian need, to align to the European The 
sustainable development has strong support from the European Union and it permanently promotes sustainable principles. At a global level, there are differences in the existent economic and social resources and that is why a uniformity is being appreciated as much as possible of the development's principles. In this UN (United Nations, 2018) framework, it contributes with a significant share in international terms to boost sustainable development and the protection of nature. Later, the reinforcement of the internal and external policies and the approval to promote it is the objective of the European Union regarding the negligence of sustainable development and comabtting poverty. Romania wants to advance in this competition and it has started from implementing legislative measures for the financial support of the development. Combatting poverty and increasing the standard of living is the proof of active participation to European policies and the expansion of the partnership collaborations on a regional and external level in domains prioritary to the National Strategy. By allocating the financing from the gross income or the GDP for development, Romania proposes for 2020-2030 a better sustainable development and it wants to earn the status of supporter of resources and national alignment, cooperation recognized fully in the European Union.

The focus is put on developing the human factor for, only through its development, the condition of life can improve. Our country has invested through previous strategic programs for the development of the human capital to encourage labor market. The action towards decentralization can assure the access from the get go to a quality education or professional forming, these being national strategic objectives planned for 2020-2030. A sustainable development is possible only through technology, innovative methods. Romania has complied from this point of view and through the government it took the measures necessary to develop research. In the future, there is the desire to evolve in knowledge, innovation, especially in economy and in the social environment by combining resources of environment with resources of social. Up until 2020 refining the legislation regarding innovation and automatically the sums that will be allocated, will rise. The allocation coming from the GDP is wanted and up until 2030 allocating larger sums for national research and for sustainable research is wanted as well (Ministry of Environment, 2008).

Thus, highlighting the objectives and the structure of the regional development strategy has high goals that need implication and coordination, but the advantage is that it will not start from scratch, Once Romania has adhered to the European Union, the country had to rise to certain standards, but the disadvantage is that the standards have evolved in a small manner as against the level of other countries. Today, Romania is placed at the level of countries under development and the work that needs to be done for it to become a developed country is found in the development strategy for 2020-2030.

\section{Conclusions}

Considering the aforementioned, I have come to the conclusion that Romania's strategy of sustainable development is according to the principles of sustainable development having common plans of action. A great deal of attention has been specifically given to the domains which target climatic changes to reduce emissions, harmful effects and the implication in the fight against global warming is being noted, calling out to the domains of transport, production and natural resources management and we consider directing our attention towards these an necessary imperious thing.

Judging by these considerations we believe that the actual legislation has traced the directions of action of the economic entities and implicitly of the accounting model from within the entity. Adapting the accounting models to the process of sustainable development is not facile to every entity in Romania, but we do believe that the strategy of sustainable development of Romania offers support during the implementation process. In the long term, 
by respecting everyhting mentioned before in this paper, Romania's strategic plan for 2020-2030 is the perfect formula to reach European standards regarding social, environment and economy, calling out to the three pylons of the sustainable development. We can talk about an advantage that Romania has in the integration of the sustainable development in the accouting model because, the initiation of the plans and implementation of the projects of sustainable development have as basis promoting policies of environment, social and economy from the perspective of different domains. Debating the assumed objectives, organizing programs and strategies of education in the domain of sustainable development are key elements which can be applied at the accounting model's level. Respecting the forementioned, the integration of the aspects of the sustainable development process specific to the strategy completes the entity's accounting model.

We consider that the tie created between the common objectives of the sustainable development and the strategy of development represents an advantage and the Development Strategy of Romania will not affect the integration of the accounting model in the process of sustainable development.

Acknowledgements: A preliminary version of this paper was presented at the 9th International Conference of Doctoral Students and Young Researchers "Emerging Markets Economics and Business", 21 November 2018, Oradea - Romania and published in the Proceedings of the 9th International Conference of Doctoral Students and Young Researchers, University of Oradea, December 2018.

\section{References}

Caraiani, C., Lungu, C., Dascălu, C., and Colceag, F., 2015. Green Accounting Initiatives and Strategies for Sustainable Development, IGI Global.

Cămăşoiu, C., 1994. Economia şi sfidarea naturii, Bucureşti: Editura Economica..

Man, M., and Ciurea, M., 2016. Transparency of Accounting Information in Achieving Good Corporate Governance. True View and Fair Value, Social Sciences and Education Research Review, No. 3(1), pp. 41-62.

Cramer, J., 2004. Making Sense of Corporate Social Responsibility. Journal of Business Ethics, 55 (2), pp. 215-222.

Dachin, A., (coord), Târhoacă, C., Goschin, Z., Huidumac, C., Marinescu, C., Rogojanu, C., 2003. Evaluări ale dezvoltarii durabile in România, Bucuresti: Editura ASE.

Dima, I. C., and Man, M., 2013. Considerations on the strategy for sustainable development of companies under the consitions of current globalisation, Science Series Data Report, 5 (5), pp. 66-75, Available at: http://www.ssdr.sciencerecor d.com/archive/index.php/?volume=5\&issue=5, [Accessed 12 October 2018].

Gherasim, Z., 2002. Influenţele tehnologiilor informaţiei şi ale comunicaţiilor asupra dezvoltării durabile, Buletinul AGIR, Dezvoltarea durabilă, Bucharest, Year VII (4, OctoberDecember), pp. 4-10.

Man, M., Nedelcu, M.V., and Oprea, C., 2018. Contabilitate Manageriala, Bucuresti: Editura Didactica si Pedagogica RA.

Man, M., and Vasile, E., 2012. Current dimension of environmental management accounting. Procedia-Social and Behavioral Sciences, 62, pp. 566-570.

Platon, V., 1997. Protecţia mediului şi dezvoltarea economică, Bucuresti: Editura Didactică şi Pedagogică.

Popescu, M.D., 1999. Globalizarea şi dezvoltarea trivalentă, Bucuresti: Editura Expert., Smith, J., 1975. A source of information. In: W. Jones, ed. 2000. One hundred and one ways to find information about health. Ch. 2. Oxford: Oxford University Press. 
Ministerul Mediului, 2008. Strategia Naţională pentru Dezvoltare Durabilă a României Orizonturi 2013-2020-2030, [Online] Available at: http://www.mmediu.ro/beta/wp-content/u ploads/2012/06/2012-0612dezvoltaredurabilasnddfinalromana2008.pdf [Accessed 10 October 2018].

National Agency for Enviromental Protection, [Online] Available at: http://www.anpm.ro/dez voltare-durabila [Accessed 25 October 2018].

Natura 2000 Coalition Romanian Federation, [Online] Available at: https://natura2000. ro/ce-este-reteaua-natura-2000/ [Accessed 15 October 2018].

The United Nations (UN), World's Largest Lesson [Online] Available at: https://www.tes.c om/worldslargestlesson/ [Accessed 25 October 2018].

\section{Bio-note}

Maria-Mădălina Bogeanu-Popa is a PhD student of the Doctoral School of Economic Sciences, Faculty of Economics and Business Administration, University of Craiova, România. As a PhD student, Maria-Mădălina focused on discovering the way Romania's strategy of development will affect the integration of the sustainable development in the accounting of Romanian entities. 